\title{
The role of monoclonal antibodies as biologic agents in the evidence based treatment of Sino-nasal diseases
}

\author{
Biyolojik ajan monoklonal antikorların Sino-nazal hastalıklarda kanıta \\ dayalı tedavideki yeri
}

\author{
Öner ÖZDEMiR $\odot$
}

\begin{abstract}
Biological therapy (biotherapy) performed using biological response modifiers is sometimes utilized to manage allergic disorders. Here, biological agents modifying Th2 type response dominant diseases e.g. allergic rhinitis are discussed under the light of current literature. Seventy-88\% of asthmatic patients have sinonasal symptoms and chronic rhinosinusitis patients with nasal polyposis are more likely to develop concomitant asthma. Due to common pathophysiology of allergic asthma and sinonasal diseases, it is supposed that patients concurrently suffering from both diseases relieve from their symptoms with omalizumab. Like the beneficial effects of omalizumab as add-on treatment in uncontrolled persistent asthma, omalizumab has been shown to improve symptoms and quality of life in patients with ragweedand birch-induced seasonal and perennial allergic rhinitis. The use of anti-IgE (omalizumab) in asthma management has also some advantages, comprising simultaneous treatment of other IgE-mediated disorders such as allergic rhinitis, an superior safety profile and an easily applicable dosing. Nasal polyp patients have mucosal eosinophilia because of significantly increased levels of IgE antibodies and with significantly increased IL-5 tissue expression. High IL-5 level was recently found to be associated with Staphylococcus aureus enterotoxins rather than atopy have provoked researchers to investigate the clinical role of IL-5blocking strategies. Consequently, mepolizumab and reslizumab have been tried in nasal polyp patients for proof-of-concept studies. The anti-IL-5 monoclonal antibodies reduced nasal polyp scores, but did not considerably improve nasal symptom scores. Due to the important role of IL-4 and IL-13 in the pathogenesis of eosinophilic nasal polyposis, dupilumab was tried as a possible therapeutic agent as well.
\end{abstract}

Keywords: Biotherapy, allergic rhinitis, nasal polyposis, omalizumab, reslizumab Received: 26.06 .2018

Accepted: 25.07.2018

Sakarya University, Medical Faculty, Division of Allergy and Immunology, Department of Pediatrics, Research and Training Hospital of Sakarya University, Adapazarı, Turkey

Yazışma adresi: Öner Özdemir, Sakarya University, Medical Faculty, Division of Allergy and Immunology, Department of Pediatrics, Research and Training Hospital of Sakarya University, Adapazarı, Turkey

e-mail: ozdemir_oner@hotmail.com

Yazarın ORCiD bilgileri:

Ö.0̈. 0000-0002-5338-9561 öz

Biyolojik yanıtı modifiye eden ajanlarla yapılan biyolojik tedavi (biyoterapi) bazen alerjik hastalıkların tedavisinde kullanılır. Burada, alerjik rinit gibi baskın Th2 tip yanıtının olduğu hastalıkları modifiye eden biyolojik ajanlar güncel literatür verileri ışı̆ııda tartışılacaktır. Astım hastalarının \%70-88'inde sinonazal semptomlar ve nazal polipli kronik rinosinuzit hastalarında eşzamanlı astım geliştirme olasılığı vardır. Allerjik astım ve sinonazal hastalıklardaki ortak patofizyolojiden dolayı, omalizumab kullanım sonrası hastaların bu hastalıkların semptomlarından kurtulması beklenir. Omalizumabın ek tedavi olarak kontrolsüz persistan astımdaki yararı gibi, ragweed (kanarya otu) ve huş ağacı (birch) ile indüklenen mevsimsel ve perennial allerjik rinitli hastalarda semptomları düzelttiği ve yaşam kalitesini artırdığı da gösterilmiştir. Astım tedavisinde anti-ıgE (omalizumab) kullanımı IgEaracılı alerjik rinit gibi diğer bir allerjik hastalığın tedavisi, üstün güvenlik profili ve kolay uygulanabilir doz sıklığı sağlamak gibi bazı avantajları da barındırır. Nazal polip hastaları anlamlı yüksek IgE antikor titresi ve artmış doku IL-5 ekspresyonundan dolayı mukozal eozinofiliye sahiptir. Yüksek IL-5 düzeyinin atopiden daha çok Stafilokok aureus enterotoksinlerine bağlı olduğunun gösterilmesi araştırıcıların IL-5 bloke eden stratejilerin araştırılmasına yol açmıştır. Sonuçta, mepolizumab ve reslizumab kavram-kanıt ilaç çalışmaları dâhilinde nazal polipli hastalara denenmiştir. Anti-IL-5 monoklonal antikorlar nazal polip skorlarını düşürmüş fakat nazal semptom skorlarını önemli derecede düzeltmemiştir. Teorik olarak IL-4 ve IL-13'ün eozinofilik nazal polipoz patogenezindeki öneminden dolayı, dupilumab potansiyel tedavi şekli olarak denenmiştir.

Anahtar kelimeler: Biyoterapi, allerjik rinit, nazal polipoz, omalizumab, reslizumab 


\section{Giriş}

$\mathrm{Bu}$ derlememizde allerjik sino-nazal hastalıklarda biyolojik ajanların, özellikle monoklonal antikor (MAb)'ların, kanıta dayalı tedavideki yerinden söz etmek istiyoruz. Sino-nazal hastalık ile sinüslerin ve burnun allerjik hastalıkları olan allerjik sinüzit, rinit, rino-sinüzit ve nazal polip (NP)'leri kastedilmektedir. En iyi bilinen ve en sık kullanılan MAb gibi biyolojik ajanların tedavide kullanılmasına "biyolojik tedavi (biyoterapi)" denilmektedir ${ }^{1}$. Biyoterapi, vücudun ya da organizmanın verdiği biyolojik yanıtı modifiye edici biyolojik ajanların kullanıldığı tedavi yöntemidir. Kullanılan ajanlar, tabii ya da suni maddeler olup, hücrelerin işlevlerini değiştirme kapasitesine sahiptirler. Hatta onkolojik hastalıklarda kullanılan bazılarında olduğu gibi hücreyi öldürür, büyümesini kontrol eder veya değiştirler. Allerjik hastalıklarda kullanılan diğer benzerleri de kişinin immün sisteminin güçlendirir, semptomları kontrol eder veya tedavinin yan etkilerini hafifletir. Bu etkileri de immün sistemin değişik yolak (pathway)'larını kullanarak ortaya çıkarırlar ${ }^{2}$. Allerjik hastalıkların tedavisinde gereksinim duyulduğunda ya da çaresiz kalındığında biyolojik tedavi gündeme gelmektedir.

Bu makalede, daha çok allerjik hastalıklar üzerindeki etkisini değerlendireceğimizden, T-helper 2 (Th2) hücrelerinin ve bu yolakta onunla ortak çalışan B hücresinin IgE antikor üretimine ve eozinofil üzerine sinyaline etkili olan biyolojik ajanlar/MAb'ların üzerinde duracağız. Biyolojik ajanlar Th2 yanıtının baskın olduğu astım dışında yine diğer allerjik hastalıklar da (besin alerjisi, atopik dermatit, eozinofilik hastalılar) ve ürtikerde de kullanılmaktadır. Th2 cevabının belirgin olduğu allerjik astımda bazı biyolojik ajanların/MAb'ların (anti-IgE: omalizumab (oMAb), anti-IL (interlökin)-5: mepolizumab ve reslizumab) kullanımı Amerikan FDA tarafından onaylanmış, bazıları hala klinik deneme aşamasında (benralizumab: anti-IL-5R $\alpha$, tralokinumab: anti-IL-13, dupilumab: anti-IL-4R $\alpha$, AMG-157: anti-TSLP) ve diğerleri de (Iigelizumab, quilizumab, lumiliximab, lebrikizumab) kullanımdan bile kaldırımıştı ${ }^{2,3}$.

$\mathrm{Bu}$ derlemede, anti-IgE-bazlı biyolojik ajan (MAb)'lardan kısaca söz edildikten sonra özellikle omalizumab ve anti-IL-5 ajanlar olan reslizumab ve mepolizumabın allerjik sino-nazal hastalıklarda kullanımı üzerinde durulacaktır.

\section{Biyolojik Ajan Monoklonal Antikorlar}

1975 yılında Köhler ve Milstein ${ }^{4}$ tarafından tanımlandıktan sonra teşhis ve tedavi kullanılmaya başlanmışlardır. Bu antikorlar, belirli bir antijene immünize edilen hayvan (fare) hücre dizi/klonları tarafından üretilirler. En sık olarak B lenfosit kaynaklı myeloma hücrelerinden oluşan hibridomalar tarafından üretilirler. Bazen de transgenik fareler tarafından üretilirler. Yapıları kimerik de olabilir. Yani antikorun variable (değişken) bölgesinde fareden elde edilmiş bir kısım, geri kalan constant (sabit) kısmında ise insan antikorundan bir kısım içerir. Bu makalede anlatılacak olan ve daha sık kullanılan oMAb gibi humanize olanlar sadece "hipervariable" bölgede fareden elde edilmiş antikor kısmını içerirler. Bu antikorların türünü anlamak için son ek olan -mab öncesinde kullanılan hecelere bakmak gerekir. Son ek -mab öncesi "o" gelirse fare kaynaklı, "u" varsa insan, "xi" varsa kimerik ve "zu" var ise humanize antikor olduğunu düşünmek gerekiri, ${ }^{1,4}$.

\section{Anti-IgE-Bazlı Monoklonal Antikorlar}

Burada IgE etkisini engelleme üzerinden en çok çaIışılmış monoklonal antikorlardan kısaca söz edilecek ve sonra değişik sino-nazal hastalıklarda göre özellikle anti-IgE ve anti-IL-5 ajanların kullanımı anlatılacaktır.

\section{Omalizumab (rhuMAb-E25)}

Rekombinant humanize MAb'dir. Omalizumab IgE antikorunun Fc kısmına bağlanarak antikorun mast hücreye Fc\&RI üzerinden bağlanmasını engellemektedir. IgE molekülü birbirinin aynı 2 hafif ve 2 ağır zincirden oluşur. Antikorun ağır zincirinin constant parçasının üçüncü kısmına (c£3) reseptörün bağlanmasından önce oMAb bağlanarak alerjik semptomlar engellenmiş olur. Omalizumaba bağlı IgE molekülü FcદRI'nin a1- $\alpha 2$ subüniteleriyle iletişime geçemez, sinyal iletilememiş ve degranülasyon engellenmiş olur ${ }^{5}$.

Omalizumab mast ve bazofil hücre üzerine etkisi ile 
degranülasyonu ve allerjik reaksiyonu/enflamasyonu engellemekle kalmaz. Ayrıca eozinofil, B lenfosit ve dendritik hücrelerde de Fc\&RI ekspresyonunu azaltarak eozinofilleri apoptoza, dendritik hücrelerin antijen sunumuna ve B hücrelerinde IgE antikor üretimine engel olarak onları anerjik kılar. Serbest IgE'yi bağlayan oMAb, IgE ile kompleks halinde alerjenleri de bağlayabilir. Yine reseptöre bağlı IgE'nin mast hücre ve bazofildeki reseptörlerden ayrılmasını hızlandırır ${ }^{6,7}$.

Aşağıda sino-nazal hastalıklardaki kullanım detayları anlatılacak olmakla beraber, özellikle astım ve allerjik rinit (AR)'te klinik kullanımı FDA tarafından 2003'ten beri onaylıdır. Bazal IgE düzeyine göre, 3-4 haftada bir 300 mg olarak bu hastalıklarda subkutan uygulanmalıdır. Zirve plazma konsantrasyonu $1 \mathrm{mg} /$ $\mathrm{kg}$ i.v. verildiğinde $30.9 \mathrm{mg} / \mathrm{L}$ olarak bulunmuştur. Zirve plazma düzeyine ulaşma zamanı $0.15 \mathrm{mg} / \mathrm{kg}$ s.c. dozunda verildiğinde 14 gün civarında hesaplanmıştır. Yarılanma zamanı 1-4 hafta arasındadır. Serumda s.c./i.v. verildikten sonra, trimer (1 IgE+2 oMAb molekülü) ya da heksamer (3 IgE+3 oMAb molekülü) halinde bulunur ${ }^{8,9}$.

\section{Quilizumab (CEmX monoklonal antikoru, faz 1 çalışması tamamlanmış)}

B hücre reseptörü-IgE birleşiminin parçası olan membrana bağlı IgE (mlgE), izotip spesifik IgE yanıtlarını meydana getirmede esas unsurdur. IgE-ekprese eden B hücrelerinin sayısını ve IgE üretimini engellemektedir. Ağır (refrakter) astımlılar ve kronik spontan ürtikerler üzerindeki saha araştırmasında etkin görülmemiş ve klinik çalışmalarda denenmesi ve geliştirilmesi çabalarına son verilmiştir. Allerjik rinitli 36 hastada (faz 1 b çalışması) i.v. ve s.c. verilen quilizumabın güvenilirlik ve toleransı araştırılmıştır. Total ve allerjen-spesifik IgE'yi anlamlı ölçüde düşürdüğü ve kabul edilir ölçüde güvenli olduğu bulunmuştur ${ }^{10,11}$.

\section{Ligelizumab (QGE031)}

IgE'nin Cع3 bölgesine oMAb'den 50 kata kadar daha yüksek afinite ile bağlanan humanize IgG1 grubundan anti-lgE mAb'dır. Preklinik değerlendirmeler ve iki ayrı randomize plasebo kontrollü çift kör (RPKÇK) çalışmada daha yüksek oranda serbest IgE düzeyi ve alerjenle indüklenen deri testi yanıtı supresyonu bildirilmiştir. Yine atopik kişilerde, farmakodinamik etkisi daha üstün bulunmuştur. Bunlara rağmen, klinik çalışmalarda oMAb’a bariz üstünlüğü gösterilemediğinden denenmesi ve geliştirilmesi çabalarına son verilmiştir ${ }^{10,12}$.

\section{Lumiliximab (MEDI-4212: anti-CD23 monoklonal antikoru)}

Faz 1 doz artırımı güvenlik çalışması allerjik kişilerde tamamlanmıştır. FcદRI üzerinden kuvvetli şekilde alerjiye bağlı indüklenen immun ve inflamatuvar yanıt gelişimini engeller ${ }^{13}$. Ayrıca, B hücre üzerindeki FcER2 (CD23) ile çapraz olarak bağlanır ve azalmış IgE üretimine yol açar. Serum IgE düzeylerini \%40 oranında düşürür. Allerjik astım ve rinit için saha çalışmalarında başarısız bulunmuş ve klinik çalışmalarda denenmesi ve geliştirilmesi çabalarına son verilmiştir $^{2}$.

\section{Mepolizumab: Anti-IL-5 monoklonal antikoru}

Humanize anti-IL-5 mAb, Gevaert ve ark. tarafından 2011 de gerçekleştirilen bir çalışmada, çok açık eozinofilisi olan 12/20 ağır NP hastasında polip boyutunda istatistiksel anlamlı düşmeye yol açmıştır ${ }^{14}$. Aşağıda NP kısmında daha detaylı irdelenecektir.

\section{Reslizumab: Anti-IL-5 monoklonal antikoru}

Bir diğer humanize anti-IL-5 ajan olan Reslizumab, güvenilirlik ve farmakokinetiğinin incelendiği RPKÇK çalışmada, NP'li hastaların yarısında polip boyutunu azalttığı gösterilmiştir ${ }^{2,3,15,16}$.

\section{IL-4+IL-13-blokaj stratejisi: Dupilumab}

Ortak reseptör olan IL-4R $\alpha$ üzerinden IL-4 yanında IL-13 etkilerini de engeller ve IgE düzeyini ortalama \%40 oranında düşürür. IgE üretiminden bağımsız şekilde IL-4 ve IL-13 tarafından meydana getirilen diğer patofizyolojik etkileri engellendiğinden allerjik hastalıkta pozitif klinik etkileri görülür. Astım, atopik dermatit ve NP üzerine yararlı etkileri bildirilmiştir. Astımda klinik denemeleri devam etmek- 
le beraber, NP tedavisindeki denemeleri de faz III aşamasındadı $\mathbf{r}^{2,3,16}$.

\section{IL-13-blokaj stratejisi (IL-13 monoklonal antikoru)}

Tralokinumab ve lebrikizumab bunların örneğidir. Dupilumab'ın, bu ikisi üzerine hem IL-4 hem de IL13'ün bloke edici etkisi olduğundan teorik olarak avantajı vardır. Fakat başarısız bulunduğundan dolayı, astımda kullanılan lebrikizumabın geliştirilmesi çabaları durdurulmuştur. Tralokinumabın ise astımda klinik deneme çalışmaları devam etmektedir².

\section{Anti-TNF- $\alpha$ monoklonal antikoru}

TNF- $\alpha$ 'nın aynı zamanda allerjik inflamasyonda, ortama eozinofil, mast ve $T$ hücrelerini çekerek, etyopatogenezde rolü olduğu sanılmaktadır. Hem Th2 sitokinlerinin salınımı hem de allerjik inflamasyon bölgesine Th2 hücrelerinin göçü için önemlidir. Allerjik bozukluklarda mast hücreleri ve makrofajlar IgEaracılı mekanizmalarla TNF- $\alpha$ 'yi üretirler. Çoğu zaman IgE, IL-4-ilişkili bir yolak üzerinden salınır ve TNF- $\alpha$, IgE üretiminde IL-4'ün rolünü baskın kılar. Allerjik inflamasyon ve TNF- $\alpha$ arasındaki ilişkiye rağmen, $A R^{\prime}$ nin tedavisinde TNF- $\alpha$ inhibitörlerinin etkinliği araştırılmamıştır. İfliksimabın alerjik semptom skorlarını azalttığı gösterilmiştir. Bu anti-allerjik etki hem Th2 sitokinlerini, total ve spesifik IgE düzeylerini bastırarak hem de burun mukozasına eozinofillerin yerleşmesini engelleyerek gerçekleştirir. Bazı klinik öncesi araştırmalarda TNF- $\alpha$ antikorlarının anti-allerjik etkinliği de gösterilmiştir ${ }^{17,18}$.

\section{Anti-lgE (Omalizumab) Monoklonal Antikorunun Allerjik Sino-Nazal Hastalıklarda Kullanımı}

Önceki çalışmalarda, mevsimsel allerjik rinit (MAR) ve perennial allerjik rinit (PAR) da, semptomları azaltmada ve yaşam kalitesini artırmada etkinliği gösterilmiştir. Burada önemli olan konu, oMAb serum serbest IgE'yi doza bağlı düşürdüğünden ve semptom skoru da allerjen spesifik IgE düzeyine bağlı olduğundan yeterli dozda verildiğinde etkin olduğunun gösterilmiş olmasıdır. Yine bu çalışmalarda, beraberinde kullanılabilen antihistaminik ilaçların etkinliğini de artırdığı görülmüştür².

\section{Mevsimsel Allerjik Rinit}

Ragweed (kanarya otu) Poleni-ile Indüklenen Mevsimsel Allerjik Rinit

Illk olarak Casale ve ark. ${ }^{19}$ tarafından 1997 yılında adolesan ve erişkin Amerikan hastalarında RPKÇK doz ayarlama çalışması yapılmıştır. Çalışmada, yeterli dozda oMAb verilmediğinden kontrole göre anlamlı fark gösterilememiştir.

Daha sonra ikinci çalışma yine Casale ve ark. tarafından 2001 yılında yapılan çalışmadır. Bu daha geniş çapta, çok merkezli, RPKÇK, paralel grup içerecek şekilde gerçekleştirilmiştir. İki yıldır orta-ağır Ragweed'e bağlı rinitli 536 hasta (plasebo sayısı: 134) üzerinde yapılmıştır. Bazal total IgE değeri 30-700 IU/ $\mathrm{mL}$ arasındaki hastalar bu çalışmada, 3 rejimden birine sokulmuştur. Bazal IgE konsantrasyonuna göre 50 mg (n:137), 150 mg (n:132), 300 mg (n:126) oMAb her 3-4 haftada bir s.c. verilmiştir. IgE değeri 151-700 $\mathrm{IU} / \mathrm{mL}$ arasındakilere, 3 haftada bir verilmiştir. Polen sezonundan 2 hafta önce ilaca başlanılmıştır. On iki hafta ilaç verilimi sonrası hastalar 12 hafta da takip edilmişlerdir. Araştırmada, özellikle 300 mg alanlarda anlamlı şekilde; nazal, oküler semptom şiddet skorları, kurtarıcı ilaç kullanımı, rinit yaşam kalite skorlaması, iş ya da okul gün kaybı farklı saptanmıştır. Yan etki sıklığı kontrol grubu ile benzer bulunmuş, yalnızca 2 hastada (\%0.5) ilaç-ilişkili ürtiker saptanmıştır. Böylece, en etkin doz 3-4 haftada bir s.c. verilen 300 mg olmuştur ${ }^{20}$.

Birch (huş ağacı) Poleni-ile indüklenen Mevsimsel Allerjik Rinit

Amerika'dan sonra Avrupa'dan Skandinav ülkelerini içeren çok merkezli, RPKÇK, 251 hasta (plasebo grubu, 2:1 oranında) üzerinde, 300mg oMAb verilerek etkinliğin karşılaştırıldığı bir çalışma Adelroth ve ark. ${ }^{21}$ tarafından 2000 yılında bildirilmiştir. Bazal IgE: 30-150 IU/mL olanlar, 0. ve 4. haftada (2 doz); bazal IgE: >150 IU/mL olanlar, 0., 3., 6. haftalarda (3 doz) oMAb şeklinde verilmiştir. Bu çalışmada, 3 kişide, hafif lokalize ürtiker gözlenmiştir. Nazal ve oküler semptom şiddet skorlamaları, yaşam kalite ve medikasyon skoru anlamlı şekilde farklı bulunmuştur. Sonuç ola- 
rak, Ragweed ile olduğu gibi bazal IgE değerlerine göre verilen $300 \mathrm{mg}$ doz çok etkin bulunmuştur.

Japon Sedir Ağacı Poleni-ile indüklenen Mevsimsel Allerjik Rinit

Okubo ve ark., 222006 yılında Japonya'dan bildirdikleri RPKÇK çalışmada, 100 orta-ağır Japon sedir ağacı poleni-ile indüklenen MAR'lı hasta üzerinde, 150$375 \mathrm{mg}$ dozunda oMAb denenmiştir. Tedavi sonrası değerlendirmede nazal, oküler, medikasyon skorları azalmıştır. Semptom azalışı ile düşük serbest IgE düzeyi direkt ilişkili bulunmuştur.

\section{Perennial Allerjik Rinit}

2003 yılında Chervinsky ve ark. RPKÇK bir çalışmada, 2 yıldır süren orta-ağır PAR'ı olan 289 hasta üzerinde (12-70 yaş, plasebo sayısı: 145/289), 16 hafta boyunca s.c. oMAb veya plasebo kullanmıştır. Perennial (akar, köpek veya kedi) allerjenlerden birine bu hastaların duyarlığı mevcuttu. Bazal total serum IgE seviyesi $30-700 \mathrm{IU} / \mathrm{mL}$ arasında idi. Omalizumab ayda 1 veya 2 ve $0.016 \mathrm{mg} / \mathrm{kg}$ doz her IgE IU/mL olacak şekilde kullanılmıştır. Nazal semptom şiddet skorlamaları, medikasyon skoru, rinit yaşam kalite skoru kontrole göre anlamlı şekilde farklı bulunmuştur. Hastalara sorulduğunda oMAb tedavisi etkin bulunmuştur. İmmunoterapi veya nazal kortikosteroid tedavisine yanıtsız hastalar da dahi etkin olduğu gösterilmiştir ${ }^{23}$.

\section{Perennial Allerjik Rinit ve Konkomitant Allerjik Astım (SOLAR çalışması)}

Vignola ve ark. ${ }^{24} 2004$ yılında, RPKÇK, "Solar" diye adlandırılan çalışmada, 405 eşzamanlı 2 yıldır süren orta-ağır PAR ve kontrolsüz persistan allerjik astımlı adolesan ve erişkinde oMAb tedavisinin etkinliğini denemişlerdir. Bu hastalarda, bazal IgE seviyesi: 30$1.300 \mathrm{IU} / \mathrm{mL}$ arasında ve herhangi bir indoor (ev içi) alerjene atopileri vardı. Tedavi sırasında rinitlilerde RQoL- ve astımlılarda yaşam kalitesini değerlendiren -AQoL- skorları orta-ağır derecede hastalığa sahip olduklarını göstermekteydi. Bu hasta grubuna 28 hafta boyunca, her IgE IU/mL birimi başına $0.016 \mathrm{mg} /$ kg'dan dozunda oMAb her 4 hafta için verildi. Tedavi sonrası yapılan değerlendirmede, astım egzaserbas- yonunun daha az, astım ve rinit semptom skorları daha düşük, ve yaşam kalite skorları daha iyi saptanmıştır. Hastalar ve araştırıcılar astım-rinit oMAb'ın tedavi etkinliğini iyi veya kusursuz olarak tanımlanmıştır.

\section{Allerjik Rinit Tedavisinde Omalizumabın Spesifik İmmunoterapi Üzerine Etkisi}

Omalizumab tedavisi spesifik immunoterapi (SIT)'nin yan etkisini azaltmak, riskli gruplara da uygulanabilmesini sağlamak, SIT tedavi etkinliğini uzatmak, tolerans gelişmesine yardımcı olmak amacıyla kullanılmaktadır ${ }^{9}$. SIT ile biyolojik ajan olarak literatürde yalnızca oMAb kullanılmıştır. Omalizumab SIT öncesinde, doz yükleme aşamasında, allerjenin pik sezonunda kullanılmaktadır ${ }^{3}$.

2002 yılında Kuehr ve ark. ${ }^{25}$ RPKÇK bir çalışmada, 6-17 yaş arası 221 orta-ağır MAR'lı hastada, Birch (huş ağacı) ve Grass (ot) polen alerjisine karşı SIT alan hastalarda, oMAb eklenip etkileri gözlenmiştir. Semptom ve medikasyon skorlarının oMAb alan gruplarda düzeldiği görülmüştür.

2006 yılında Casale ve ark. ${ }^{26}$ ragweed-ile indüklenen MAR'lı rush immunoterapi alan 159 hastada, oMAb tedavisi 9 hafta önce başlanmış ve oMAb tedavisi başlandıktan sonra da 12 hafta devam etmiştir. Genel olarak yan etkilerde \%40 azalma ve adrenalin gerektiren anafilakside \%78 azalma saptanmıştır. İmmunoterapi öncesi başlanılan oMAb anafilaksi olasılığını 5 kat azaltmıştır. Günlük nazal semptom şiddetini de düşürmüştür.

\section{Allerjik Rinitte Omalizumab Etkinlik ve Doz Kriterleri}

Özellikle AR hastalarında yapılan çalışmalarda, oMAb'ın serum IgE değerini $<25 \mathrm{IU} / \mathrm{mL}$ (25 ng/ml) olacak şekilde düşürecek dozda kişiye verilmesi gerektiği saptanmıştır. Hatta bazı araştırıcılar, serum IgE: $<10 \mathrm{IU} / \mathrm{mL}$ olacak şekilde dozun verilmesi gerektiğini vurgulamaktadırlar. Bunun için de serumda 1015:1 omalizumab/total IgE oranını sağlayacak dozda oMAb verilmelidir. Bunu sağlayacak doz ve verilme aralığı 2-4 haftada bir verilen 150-375 mg oMAb ile sağlanabilir ${ }^{27}$. 


\section{Kronik Rinosinuzit, Allerjik Rinit Ve/Veya Konkomitant Astımın Beraber Bulunduğu Hastalıklarda Kullanım}

Kronik sinüzit eşzamanlı bakteriyel kolonizasyonun olduğu paranazal sinus mukozasının persistan inflammasyonudur. Kadın ve yaşlı erişkinlerde yüksek prevalansa sahiptir. Amerikan toplumunda sıklığı $\% 14$, Kanada'da erişkinlerin \%5 oranında bulunmuştur. Amerika'da hala yıllık 20 milyon doktor vizitine, Kanada'da yıllık 1 milyon reçeteye neden olmaktadır. Kronik rino-sinuzitli hastaların \%30-94'ünde atopi saptanır. Astım, AR ile sıklıkla beraber bulunur. Patofizyolojisinde eozinofil ve Th2 sitokinlerinin varsayllan rollerinden dolayı IgE ana inflamatuvar medyatör olarak kabul edilir. KRS'li Beyaz ırkın (Caucasian) $\% 80$ 'ninde lokal poliklonal IgE infiltrasyonu ve aynı anda eozinofilik doku inflammasyonu mevcuttur ${ }^{28}$.

Allerjik Rinit ve KRS sıklıkla beraber bulunmakla beraber, bazen astımla birlikte de olabilmektedir. Eozinofilik KRS+Refrakter AR'li hastalar oMAb ile daha anlamlı düzelme gösterirler ${ }^{29}$.

\section{Refrakter Allerjik Fungal Rinosinuzit ve (Orta-Ağır)}

Astım Omalizumab tedavisi refrakter allerjik fungal rinosinuzit ve (orta-ağır) astım için potansiyel ek tedavi olarak düşünülebilinir. Evans ve Coop ilk defa 2014 yılında refrakter (tedaviye dirençli) allerjik fungal rinosinüzitli hastalar üzerinde, oMAb tedavisinin olumlu etkisini bildirmişlerdir ${ }^{30,31}$.

\section{Kronik Rinosinüzit ve Allerjik Astım}

Omalizumab KRS'nin allerjik astım ile beraberliğinde tedavinin daha başarılı olduğu spirometrinin içinde olduğu değerlendirme ölçütleriyle gösterilmiştir ${ }^{32}$.

Astımlıların \%70-88'inde sinonazal semptomların bulunduğu ve AR-Astım gelişimi arasında yakın ilişki bilinmektedir ${ }^{33}$. Yine kronik rinosinüzit ve nazal polip (KRSNP)'in beraber bulunduğu hastalarda çoğu zaman astım da aynı anda bulunur. Astımla beraber AR'si olan hastalarda oMAb etkin olması beklenir. Bir çalışmada, rinit üzerine ek pozitif düzeltici etkisinin 3.6 kat daha fazla olduğu bulundu ${ }^{34}$.

\section{Nazal Polip, Kronik Rinosinüzit Ve/Veya Allerjik / Non-Allerjik Astımın Beraber Bulunduğu Hastalık- larda Kullanım}

Nazal polipler, nazal ve paranazal orta meatus ve etmoid hücrelerinden kaynaklanan ödematöz kitlelerdir. Genellikle toplumda \%4 oranında sıklıkta rastlanılmakla beraber, NP'li hastaların çoğu erişkin, 45 yaş üzerinde ve sıklıkla atopik değillerdir ${ }^{35}$. Bu hastalar, allerjene maruz kalsa, atopik bulunsa da, semptom ve medyatör salınımı bu hastalarda görülmez ${ }^{28,36}$. Bu hastalarda görülen serum yüksek IgE seviyelerinin ise nazal mukozadaki artmış Stafilokok aureus enterotoksini ile meydana geldiği düşünülmektedir ${ }^{37}$. Bu hastalarda Th2 polarizasyonu sonuçta IL-5 sekresyonuna, eozinofilik infiltrasyona ve IgE üretimine yol açar. Beyaz ırktaki NP'lerin $\leq \% 90$ 'nında eozinofilik infiltrasyonu olup, steroit tedavisine cevaplıdırlar. Bunlarda eşzamanlı allerjik astım bulunması sıktır². Bundan dolayı anti-IL-5 kullanımı gündeme gelmiş ve bu ajanların eozinofil apoptozuna yol açarak ve doku eozinofilisini azaltarak etkili olabileceği düşünülmektedir $^{38}$. Nazal polipli hastalarda, endoskopik cerrahi sonrasında bile nüks olabildiğinden oMAb tedavisi bunların tedavisinde efektif olabilir.

Bu hastalarda nazal dokudaki eozinofili ve yüksek IL5 'ten dolayı literatürde son zamanlarda OMAb, mepolizumab, reslizumab ve ayrıca dupilumab gibi ilaçlarla yapılan çalışmalar değişik araştırıcılar tarafından bildirilmiş ve aşağıda kısaca tartışılmıştır.

\section{i-) Omalizumab:}

Yirmi dört KRSNP+allerjik ve nonallerjik astımlı hastaya, Faz-II RPKÇK çalışmada, ${ }^{16}$ hafta boyunca verilen oMAb ile nazal semptomlar, total endoskopik NP skoru anlamlı azalmış ve BT'de Lund-MacKay (sinus opasifikasyon) skorlarında düzelme saptanmıştır. Atopiden bağımsız olarak, nazal/astım semptom ve yaşam kalite (QoL) skorları düzelmiştir. Non-atopik hastada dahi oMAb ile etkinlik gösterilmiş ve NP dokusunda lokal üretilen ve periferik alt solunum yolunda mevcut IgE'nin nötralizasyonuna bu başarı bağlanmıştır ${ }^{39}$. Bachert ve ark. ${ }^{37}$ çalışmalarında, bu hastalarda Stafilokok aureus enterotoksinlerine karşı gelişen serum IgE'sini astım şiddeti ile ilişkili bulmuşlardır. 
Vennera ve ark. ${ }^{40}$ yaptığı çalışmada, 19 KRSNP ve ağır astımlıya oMAb verildi. Tedavi öncesi \%95 intranazal steroid bağımlılığı olan bu grupta tedavi sonrasında bağımlılık \%42'ye gerilemiştir. Yine cerrahi revizyondan sakınılabilmiştir. Allerjik ve serum IgE yüksek olan hastada oMAb daha etkin olmasına rağmen, atopik olmayan NP'de anti-IgE tedavi modalitesi yenidir. Gevaert ve ark. ${ }^{39} 2013$ yılında, nonallerjik NP ve astımlılarda da etkin olduğu göstermişlerdir.

Endoskopik cerrahi uygulanmış NP ve aynı zamanda atopik astımı olan hastalarda retrospektif pilot çalışmada 4 hastaya, oMAb verilmiştir. Dört kontrol hastasına kıyasla, oMAb alanlarda nazal semptom skorları düzemiş, fakat sinus $\mathrm{BT}^{\prime}$ lerinde önemli düzelme görülmemiştir ${ }^{41}$.

\section{ii-) Mepolizumab ve Reslizumab:}

Mepolizumab ve reslizumab'ın NP skorlarını düşürdüğü fakat nazal semptom skorlarını düzeltmediği görülmüştür². Örneğin, bir çalışmada, şiddetli bilateral NP'te 6 aylık mepolizumab verilimi cerrahi gereksinimini azaltmıştır ${ }^{14}$. Bu ilaçlar bazal IL-5 değeri yüksek olanlarda daha etkin bulunmuştur.

Şiddetli NP'te mepolizumab ve reslizumab kullanımı ile yapılan faz $1 / 2$ klinik çalışmaları tamamlanmıştır. Otuz steroide dirençli /şiddetli KRSNP'li olan hasta ile yapılan RPKÇK çalışmada iki doz i.v. 750 mg mepolizumab verildiğinde, 12/20 hastanın NP skor+BT skan skorlarında anlamlı düzelme saptanmıştır ${ }^{42}$.

İki merkezden toplanan bilateral NP'li 24 kişi üzerinde yapılan RPKÇK çalışmada, tek doz i.v. reslizumab (1 veya $3 \mathrm{mg} / \mathrm{kg}$ ) eozinofili ve nasal sekresyon ECP konsantrasyonunu düşürdüğü ve 12/24 hastada NP'nin küçüldüğü gösterilmiştir. Nazal sekresyonda IL-5 artmış olanda daha başarılı olduğu gösterilmiştir ${ }^{42}$.

\section{iii-) Dupilumab:}

IL-4+ IL-13 sitokinlerinin eozinofilik NP patogenezindeki rolü bilinmektedir. Bunların her ikisini antagonize edebilen dupilumab ile RÇKPK paralel-grup olarak yapılan çalışmada intranazal steroidlere dirençli KRS+NP olan 60 erişkin hastaya haftalık dupi- lumab (600 mg s.c. yükleme dozu sonrası 300 mg) veya plasebo+mometazon furoat nazal spray 16 hafta boyunca uygulanmıştır. Endoskopik NP skoru ve Lund-Mackay sinus BT total skoru azalmıştır. Nazal poliplerde azalmaya ilaveten anlamlı nazal semptom düzelmesi gözlenmiştir ${ }^{43}$.

\section{Omalizumab Konusundaki Sistematik Derleme ve Meta-Analizler}

Son zamanda gerçekleştirilen 2870 AR hastasını kapsayan 11 çalışma üzerinde yapılan bir meta-analizde, oMAb tedavisi ile günlük nazal semptom şiddet skorunda, günlük medikasyon skoru ve yan etki riskinde anlamlı düşüklük saptanmıştır. Sonuç olarak, semptomlarda rahatlama, kurtarıcı medikasyon kullanımında azalma ve yaşam kalitesinin artma da görülmüştür ${ }^{44}$.

Yine KRS üzerine yeni bildirilen bir sistematik derlemede, yalnızca 2 çalışma dahil edilebilmiştir. Bu çaIışmalarda oMAb ile plasebo ile karşılaştırıldığında, Lund-McKay skorunda anlamlı fark olmasına rağmen, BT'de opasifikasyon yüzdesi farklı değildi. On altı haftalık tedavi sonrası klinik polip skoru düşmüştü. Yaşam kalitesi ve total nazal semptom şiddetinde fark bulunamadı. Anti-IgE tedavisinin etkinliğini gösteren yeterli bulgu halen yoktur ${ }^{45}$.

\section{Rehberlerde Omalizumab}

2013 yılı Avrupa Alerji Klinik İmmünoloji Akademisi (EAACI)'nin pediatrik rinit pozisyon makalesine göre, AR ve orta-ağır astım için diğer önerilen tedaviler etkisiz ise, oMAb tedavide kullanılacak olası (possible) ajan olarak gösterilmektedir ${ }^{46}$.

\section{Omalizumabın Yan Etkileri}

Diğer biyolojik ajanlarda net olarak bilinmemekle beraber, burada söz ettiğimiz ajanların en uzun süredir klinikte kullanılanı oMAb ile ilgili basit olan ve sık görülen ürtiker, baş ağrısı ve enjeksiyon yerindeki problemler ön plandadır ${ }^{47}$. Fakat malignansi, anafilaksi ve kardiyovasküler ve serebro-vasküler hastalıklarda artma gibi daha ciddi yan etkilere rastlandığı bazı çalışmalarda bildirilmiştir ${ }^{48}$. Anafilaksinin nadir de 
olsa belli sıklıkta gerçekleştiği bilinmektedir ${ }^{49}$. Bundan dolayı oMAb'ın ilk 3 enjeksiyonu sonrasında en az 2 saat beklenilmesi gerektiği daha sonraki enjeksiyonlarda ise en az $1 / 2$ saat beklenilmesi gerektiğini vurgulanmaktadır ${ }^{50}$. Omalizumab alan 5.000'i aşan kişi üzerinde yapılan EXCELS çalışmasında, oMAb kullananlarda malignansi olasılığının artmadığı fakat kardiyo-vasküler ve serebro-vasküler hastalıklarda artma gibi bir olasılıktan söz edilmiştir ${ }^{48}$.

\section{SONUÇ}

Omalizumab ve diğer biyolojik ajanlar son dekatta allerjik sino-nazal hastalıklarda kullanılmaya başlanılmış ve etkinlikleri bildirilmiştir. Bu başarılı sonuçların daha geniş çalışma gruplarında yinelenmesine ve etkinlik/güvenlik açısından daha detaylı çalışmalara gereksinim vardır ${ }^{51}$.

\section{Çıkar Çatışması: Yok}

\section{Finansal Destek: Yok}

\section{KAYNAKLAR}

1. Tan HT, Sugita K, Akdis CA. Novel biologicals for the treatment of allergic diseases and asthma. Curr Allergy Asthma Rep. 2016;16(10):70. https://doi.org/10.1007/s11882-016-0650-5

2. Casale TB. Biologics and biomarkers for asthma, urticaria, and nasal polyposis. J Allergy Clin Immunol. 2017;139(5):141121. https://doi.org/10.1016/j.jaci.2017.03.006

3. Boyman O, Kaegi C, Akdis M, et al. EAACI IG Biologicals task force paper on the use of biologic agents in allergic disorders. Allergy. 2015;70(7):727-54. https://doi.org/10.1111/all.12616

4. Martin-Mateos MA. Monoclonal antibodies in pediatrics: use in prevention and treatment. Allergol Immunopathol (Madr). 2007;35(4):145-50. https://doi.org/10.1157/13108225

5. Shields RL, Whether WR, Zioncheck K, et al. Inhibition of allergic reactions with antibodies to IgE. Int Arch Allergy Immunol. 1995;107:308-12. https://doi.org/10.1159/000237010

6. Prussin C, Griffith DT, Boesel KM, Lin H, Foster B, Casale TB. Omalizumab treatment downregulates dendritic cell FcepsiIonRI expression. J Allergy Clin Immunol. 2003;112:1147-54. https://doi.org/10.1016/j.jaci.2003.10.003

7. Lin H, Boesel KM, Griffith DT, et al. Omalizumab rapidly decreases nasal allergic response and FceRI on basophils. J Allergy Clin Immunol. 2004;113:297-302. https://doi.org/10.1016/j.jaci.2003.11.044

8. Özdemir Ö. Omalizumab: Pharmacological properties, primary therapeutic effect mechanisms and adverse effects. J
Otolaryngol Rhinol. 2018;4:042. doi.org/10.23937/2572-4193.1510042.

9. Stock P, Rolinck-Werninghaus C, Wahn U, Hamelmann E. The role of anti-lgE therapy in combination with allergen specific immunotherapy for seasonal allergic rhinitis. BioDrugs. 2007;21(6):403-10. https://doi.org/10.2165/00063030-200721060-00007

10. Navinés-Ferrer A, Serrano-Candelas E, Molina-Molina GJ, Martín M. IgE-related chronic diseases and anti-IgE-based treatments. J Immunol Res. 2016;2016:8163803. https://doi.org/10.1155/2016/8163803

11. Chen JB, Wu PC, Hung AF, et al. Unique epitopes on C epsilon $\mathrm{mX}$ in IgE-B cell receptors are potentially applicable for targeting IgE-committed B cells. J Immunol. 2010;184(4):174856. https://doi.org/10.4049/jimmunol.0902437

12. Arm JP, Bottoli I, Skerjanec A, et al. Pharmacokinetics, pharmacodynamics and safety of QGE031 (ligelizumab), a novel high-affinity anti-IgE antibody, in atopic subjects. Clin Exp Allergy. 2014;44(11):1371-85. https://doi.org/10.1111/cea.12400

13. Poole JA, Meng J, Reff M, Spellman MC, Rosenwasser LJ. AntiCD23 monoclonal antibody, lumiliximab, inhibited allergeninduced responses in antigen-presenting cells and T cells from atopic subjects. J Allergy Clin Immunol. 2005;116(4):780-8. https://doi.org/10.1016/j.jaci.2005.07.007

14. Gevaert P, Lang-Loidolt D, Lackner A, et al. Nasal IL-5 levels determine the response to anti-IL-5 treatment in patients with nasal polyps. J Allergy Clin Immunol. 2006;118:1133-41. https://doi.org/10.1016/j.jaci.2006.05.031

15. Tabatabaian F, Ledford DK, Casale TB. Biologic and new therapies in asthma. Immunol Allergy Clin North Am. 2017;37(2):329-43. https://doi.org/10.1016/j.iac.2017.01.007

16. Chiarella SE, Sy H, Peters AT. Monoclonal antibody therapy in sinonasal disease. Am J Rhinol Allergy. 2017; 31(2):93-5. https://doi.org/10.2500/ajra.2017.31.4412

17. Genç $S$, Adin S. Allerjik rinitte diğer farmakoterapi seçenekleri ve alternatif tedavi yöntemleri. Asthma Allergy Immunol. 2013;11:59-70. http://www.aai.org.tr/index.php/aai/article/view/157/98

18. Bradding $\mathrm{P}$, Mediwake R, Feather $\mathrm{IH}$, et al. TNF alpha is localized to nasal mucosal mast cells and is released in acute allergic rhinitis. Clin Exp Allergy. 1995;25(5):406-15. https://doi.org/10.1111/j.1365-2222.1995.tb01071.x

19. Casale TB, Bernstein IL, Busse WW, et al. Use of anti-IgE humanized monoclonal antibody in ragweed-induced allergic rhinitis. J Allergy Clin Immunol. 1997;100:110-21. https://linkinghub.elsevier.com/retrieve/pii/ S00916749970018 4X

20. Casale TB, Condemi J, LaForce C, et al. Effect of omalizumab on symptoms of seasonal allergic rhinitis. A randomized controlled trial. JAMA. 2001;286:2956-67. https://doi.org/10.1001/jama.286.23.2956

21. Adelroth E, Rak S, Haahtela T, et al. Recombinant humanized $\mathrm{mAb}-\mathrm{E} 25$, an anti-IgE mAb, in birch pollen-induced seasonal allergic rhinitis. J Allergy Clin Immunol. 2000;106:253-9. https://doi.org/10.1067/mai.2000.108310

22. Okubo K, Nagakura T. Anti-lgE antibody therapy for Japanese cedar pollinosis: omalizumab update. Allergol Int. 2008;57(3):205-9. https://doi.org/10.2332/allergolint.R-08-164

23. Chervinsky $P$, Casale $T$, Townley $R$, et al. Omalizumab, an anti-IgE antibody, in the treatment of adults and adolescents 
with perennial allergic rhinitis. Ann Allergy Asthma Immunol. 2003;91:160-7.

https://doi.org/10.1016/S1081-1206(10)62171-0

24. Vignola AM, Humbert M, Bousquet J, et al. Efficacy and tolerability of anti-immunoglobulin $\mathrm{E}$ therapy with omalizumab in patients with concomitant allergic asthma and persistent allergic rhinitis: SOLAR. Allergy. 2004;59(7):709-17.

https://doi.org/10.1111/j.1398-9995.2004.00550.x

25. Kuehr J, Brauburger J, Zielen S, et al. Efficacy of combination treatment with anti-IgE plus specific immunotherapy in polysensitized children and adolescents with seasonal allergic rhinitis. J Allergy Clin Immunol. 2002;109:274-80. https://doi.org/10.1067/mai.2002.121949

26. Casale TB, Busse WW, Kline JN, et al. Omalizumab pretreatment decreases acute reactions after rush immunotherapy for ragweed-induced seasonal allergic rhinitis. J Allergy Clin Immunol. 2006;117:134-40. https://doi.org/10.1016/j.jaci.2005.09.036

27. Belliveau PP. Omalizumab: a monoclonal anti-IgE antibody. Med Gen Med. 2005;7(1):27. https://www.ncbi.nlm.nih.gov/pmc/articles/PMC1681435/

28. Verbruggen $K$, Van Cauwenberge $P$, Bachert C. Anti-IgE for the treatment of allergic rhinitis - and eventually nasal polyps? Int Arch Allergy Immunol. 2009;148:87-98. https://doi.org/10.1159/000155739

29. Tajiri T, Matsumoto H, Hiraumi H, et al. Efficacy of omalizumab in eosinophilic chronic rhinosinusitis patients with asthma. Ann Allergy Asthma Immunol. 2013;110:387-8. https://doi.org/10.1016/j.anai.2013.01.024

30. Evans II MO, Coop CA. Novel treatment of allergic fungal sinusitis using omalizumab. Allergy Rhinol. 2014;5:172-4. https://doi.org/10.2500/ar.2014.5.0098

31. Gan EC, Habib AR, Rajwani A, Javer AR. Omalizumab therapy for refractory allergic fungal rhinosinusitis patients with moderate or severe asthma. Am J Otolaryngol. 2015;36(5):672-7. https://doi.org/10.1016/j.amjoto.2015.05.008

32. Clavenna MJ, Turner JH, Samuelson M, Tanner SB, Duncavage J, Chandra RK. Differential effect of omalizumab on pulmonary function in patients with allergic asthma with and without chronic rhinosinusitis. Allergy Asthma Proc. 2016;37(1):23-6. https://doi.org/10.2500/aap.2016.37.3923

33. Bresciani $M$, Paradis $L$, Des Roches $A$, et al. Rhinosinusitis in severe asthma. J Allergy Clin Immunol. 2001;107:73-80. https://doi.org/10.1067/mai.2001.111593

34. Humbert M, Boulet LP, Niven RM, Panahloo Z, Blogg M, Ayre G. Omalizumab therapy: patients who achieve greatest benefit for their asthma experience greatest benefit for rhinitis. Allergy. 2009;64(1):81-4. https://doi.org/10.1111/j.1398-9995.2008.01846.x

35. Bachert C, Zhang L, Gevaert P. Current and future treatment options for adult chronic rhinosinusitis: Focus on nasal polyposis. J Allergy Clin Immunol. 2015;136(6):1431-40. https://doi.org/10.1016/j.jaci.2015.10.010

36. Johansson L, Akerlund A, Holmberg K, Melén I, Bende M. Prevalence of nasal polyps in adults: the Skovde populationbased study. Ann Otol Rhinol Laryngol. 2003;112:625-9. https://doi.org/10.1177/000348940311200709

37. Bachert $C$, Gevaert $P$, Howarth $P$, Holtappels $G$, van Cauwenberge $P$, Johansson SG. IgE to Staphylococcus aureus enterotoxins in serum is related to severity of asthma. J Allergy Clin Immunol. 2003;111(5):1131-2.

https://linkinghub.elsevier.com/retrieve/pii/

\section{S00916749035128 66}

38. Tsetsos N, Goudakos JK, Daskalakis D, Konstantinidis I, Markou K. Monoclonal antibodies for the treatment of chronic rhinosinusitis with nasal polyposis: a systematic review. Rhinology. 2018;56(1):11-21. https://doi.org/10.4193/Rhin17.156

39. Gevaert P, Calus L, Van Zele T, et al. Omalizumab is effective in allergic and nonallergic patients with nasal polyps and asthma. J Allergy Clin Immunol. 2013;131(1):110-6.e1. https://doi.org/10.1016/ j.jaci.2012.07.047

40. Vennera Mdel C, Picado C, Mullol J, Alobid I, BernalSprekelsen M. Efficacy of omalizumab in treatment of nasal polyps. Thorax. 2011;66:824-5. https://doi.org/10.1136/thx.2010.152835

41. Penn R, Mikula S. The role of anti-IgE immunoglobulin therapy in nasal polyposis: a pilot study. Am J Rhinol. 2007;21:428-32. http://journals.sagepub.com/doi/abs/10.2500/ajr.2007.21.3060

42. Gevaert P, Van Bruaene N, Cattaert T, et al. Mepolizumab, a humanized anti-IL-5 mAb, as a treatment option for severe nasal polyposis. J Allergy Clin Immunol. 2011;128:989-95. https://doi.org/10.1016/j.jaci.2011.07.056

43. Bachert C, Mannent L, Naclerio RM, et al. Effect of subcutaneous dupilumab on nasal polyp burden in patients with chronic sinusitis and nasal polyposis: a randomized clinical trial. JAMA. 2016;315:469-79. https://doi.org/10.1001/jama.2015.19330

44. Tsabouri S, Tseretopoulou X, Priftis K, Ntzani EE. Omalizumab for the treatment of inadequately controlled allergic rhinitis: a systematic review and meta-analysis of randomized clinical trials. J Allergy Clin Immunol Pract. 2014;2(3):332-40.e1. https://doi.org/10.1016/j.jaip.2014.02.001

45. Hong CJ, Tsang AC, Quinn JG, Bonaparte JP, Stevens A, Kilty SJ. Anti-IgE monoclonal antibody therapy for the treatment of chronic rhinosinusitis: a systematic review. Syst Rev. 2015;4:166.

https://doi.org/10.1186/s13643-015-0157-5

46. Roberts G, Xatzipsalti M, Borrego LM, et al. Paediatric rhinitis: position paper of the European Academy of Allergy and Clinical Immunology. Allergy. 2013;68(9):1102-16. https://doi.org/10.1111/all.12235

47. Corren J, Casale TB, Lanier B, Buhl R, Holgate S, Jimenez P. Safety and tolerability of omalizumab. Clin Exp Allergy. 2009;39(6):788-97.

https://doi.org/10.1111/j.1365-2222.2009.03214.x

48. Iribarren C, Rahmaoui A, Long AA, et al. Cardiovascular and cerebrovascular events among patients receiving omalizumab: Results from EXCELS, a prospective cohort study in moderate to severe asthma. J Allergy Clin Immunol. 2017;139(5):14891495.e5. https://doi.org/10.1016/ j.jaci. 2016. 07.038.

49. Cox L, Platts-Mills TA, Finegold I, Schwartz LB, Simons FE, Wallace DV. American Academy of Allergy, Asthma\&Immunology / American College of Allergy, Asthma and Immunology Joint Task Force Report on omalizumab-associated anaphylaxis. J Allergy Clin Immunol. 2007;120:1373-7. https://doi.org/10.1016/j.jaci.2007.09.032

50. Long A, Rahmaoui A, Rothman KJ, et al. Incidence of malignancy in patients with moderate-to-severe asthma treated with or without omalizumab. J Allergy Clin Immunol. 2014;134(3):560-7.e4.

https://doi.org/10.1016/j.jaci.2014.02.007

51. Özdemir Ö. Omalizumab and sino-nasal allergy treatment. MOJ Immunol. 2018;6(2):25-7.

https://doi.org/10.15406/moji.2018.06.00187 